\title{
The Artistic Representation of Jesus in Hermann Cohen's Aesthetics
}

\author{
Ezio Gamba $\bowtie$ \\ Theological University of Northern Italy - Turin Campus, \\ 83, Via XX Settembre, Turin, 10122, Italy \\ \ezio.gamba.1975@gmail.com
}

\begin{abstract}
Cohen deals with the question of the possibility for art to represent God or the divine in some of his works, throughout all his philosophical production, but obviously above all in his main aesthetic work, Ästhetik des reinen Gefühls (1912). We can state that in Cohen's works this problem is posed with reference to three different religious fields: Greek polytheism, Jewish monotheism and Christianity. The topic of this essay will be Cohen's thought about the artistic representation of the divine in Christianity or in Christian art through the representation of Jesus. This topic will be examined with reference both to Kants Begründung der Ästhetik (1889) and to Ästhetik des reinen Gefühls; whereas in Kants Begründung der Ästhetik Cohen devotes to the representation of Jesus just a short consideration in the historical introduction of the book, in Ästhetik des reinen Gefühls the representation of Jesus is object of far more attention. Here, Cohen's answer to the question of the possibility to represent the divine through the representation of Jesus is that Jesus' divinity, in the artistic representation of his figure, can only have a metaphorical value, the real meaning of which is that Jesus' story is the ideal story of the human being; in Kants Begründung der Ästhetik and in other writings of the 80s, on the contrary, the idea of incarnation and of the divinity of Jesus is object of a different appreciation by Cohen. The comparison between these different stances can be a contribution to the comprehension of the changes in Cohen's view of Christianity through the years.

Keywords: Hermann Cohen, Aesthetics, Jesus Christ, Christianity, Religious Art, Greek Sculpture
\end{abstract}

\section{Article history:}

The article was submitted on 08.06.2021

The article was accepted on 15.08.2021

(C) Gamba E., 2021

This work is licensed under a Creative Commons Attribution 4.0 International License https://creativecommons.org/licenses/by/4.0/ 
For citation: Gamba E. The Artistic Representation of Jesus in Hermann Cohen's Aesthetics. RUDN Journal of Philosophy. 2021;25(3):404 - 419. DOI: 10.22363/2313-2302-2021-25-3404-419

Cohen deals with the question of the possibility for art to represent God or the divine in some of his works, throughout all his philosophical production, but obviously above all in his main work on aesthetics, Ästhetik des reinen Gefühls (1912). We can state that in Cohen's works this problem is posed with reference to three different religious fields: Greek polytheism, Jewish monotheism and Christianity. Concerning this question, Greek polytheism and Jewish monotheism are mainly examined by Cohen with mutual reference to, or mutual contrast with, one another; on the contrary, Cohen's considerations about the artistic representation of the divine in Christianity are more autonomous.

The topic of this essay will be Cohen's thought about the artistic representation of the divine in Christianity or in Christian art through the representation of Jesus. However, to understand this topic, a brief introduction about Cohen's considerations (as they are exposed in Ästhetik des reinen Gefühls) on the problem of the representation of the divine in Greek polytheism and in Jewish monotheism is necessary.

In the chapter of $\ddot{A}$ sthetik des reinen Gefühls about sculpture, Cohen pays much attention to the contrast between the unrepresentability of God in monotheism and the representation of the gods in polytheism, with particular reference to Greek polytheism ${ }^{1}$. Obviously, the radical distinction of the monotheistic God from any object of nature is sufficient to clarify beyond any doubt its unrepresentability, so that the prohibition against making an image of any natural object and worshipping this image as an image of God is not a mere ritual prohibition, but a real expression of God's being and of God's unicity; so, sculpture cannot represent the monotheistic God.

Concerning the representation of the gods of Greek polytheism in Greek classic sculpture, it is necessary to remember here a fundamental thesis of Cohen's aesthetic thought, which is that the main object of artistic representation is the human being, since the fundament of art is, according to Cohen's thought, pure feeling, which expresses itself as love for the human being. The purity of this feeling means that it does not receive its object from somewhere else, it does not concern an object that is already given; on the contrary, it produces its own object. Hence, love for the human being produces the human figure ${ }^{2}$. So, the divine figures represented by Greek sculpture are human figures; moreover, they are the product of an idealization: they are ideal human figures, in the duality of the human figure, that is the figure of a man and a woman [1. Vol. II. P. 268-274]. Paying attention to this value of divine figures in Greek sculpture as ideal human figures will be useful to understand Cohen's considerations on the representation of Jesus in Christian art.

\footnotetext{
${ }^{1}$ See above all [1. Vol. II. P. 259-265].

${ }^{2}$ About Cohen's concept of figure, see [3. P. 147-152] and [4. P. 135-138].
} 
Before dealing with the considerations expressed by Cohen in Ästhetik des reinen Gefühls, it is convenient to recall other reflections, or simple hints, about the artistic representations of Jesus expressed in some of his previous works.

First of all, however, a general clarification is needed: according to Christianity, Jesus is not a mere human being, he is at the same time true human being and true God. Not merely $a$ god, as one of the gods of polytheism, but really the God of monotheism, the unique and unrepresentable God. However, Jesus, as a man, is representable. This tension is clearly expressed in some texts of the New Testament, above all in the Epistle to the Colossians, where Jesus is stated to be "the image of the invisible God" $(1,15)$. So, we can ask: is the artistic representation of Jesus a representation of God? Or: can art represent the invisible God through the representation of Jesus?

If we examine Cohen's reflections about the artistic representation of Jesus in the light of these questions, we have first to consider that, before Ästhetik des reinen Gefühls, this topic has been considered by Cohen in some of his writings of the 80s; then, like all or almost all aesthetic topics, it is not mentioned by him in the period between Kants Begründung der Ästhetik (1889) and Ästhetik des reinen Gefühls (1912). We should also note that, during this period, Cohen's perspective on Christianity changes substantially, and becomes more negative. In his writings of the $80 \mathrm{~s}$ Cohen expresses a general cultural appreciation for Christianity, recognizing to the humanization of God an important value as a cultural innovation; Cohen particularly emphasizes the ethical value of the doctrine of incarnation, which - according to him - has given monotheism a new and more authentic perspective on the human being, on its dignity and its relation with $\mathrm{God}^{3}$. However, Cohen states that the doctrine of incarnation can be the object of this cultural appreciation only under the condition that it is idealized: appreciating the doctrine does not mean believing that God has become a man and that he lived in a precise time and place; Cohen always considered this a myth. Appreciating the doctrine of incarnation means, on the contrary, thinking that the doctrine according to which God becomes human contains an important religious thought concerning the relation between God and every human being; so, in this perspective, Jesus has to be considered as an idea, not as a historical individual.

This view on incarnation also has an aesthetic side: incarnation has opened new possibilities to figurative arts, because it allows the figurative arts to deal with the divine without falling into paganism. Cohen's work in which this aesthetic side of his appreciation for the doctrine of incarnation is expressed in the clearest way is Kants Begründung der Ästhetik. This is also the first work by Cohen where the question of the artistic representation of Jesus is directly, even if briefly, dealt with. In the Historische Einleitung of this book, Cohen writes that Christianity contains in itself an intimate affinity with art, so it offers an incentive to artistic creation

\footnotetext{
${ }^{3}$ See particularly Cohen's writings Ein Bekenntnis in der Judenfrage (1880) [5. Vol. II. P. 76-77] and Zur Verteidigung (1880) [5. Vol. II. P. 95-97].
} 
[6. P. 18]. Here Christianity is compared with Greek polytheism, and it is easy to see that here Cohen has not yet developed his perspective (expressed more than twenty years later in Ästhetik des reinen Gefühls) on Greek statues of gods as ideal human figures. In Kants Begründung der Ästhetik Cohen writes that classic Greek sculpture does not idealize the human being, but, on the contrary, it idealizes gods, whereas Christian art really represents the human being in its idealization. Art can achieve the true representation of the ideal of the human being just thanks to the Christian doctrine of incarnation. Cohen writes that not the Homeric gods, but "only the suffering God, the Son of Man who loves, just the Son of Man who returns as judge could mean the ideal of the human being (Erst der leidende Gott, der liebende, ja selbst der als Richter wiedererscheinende Menschensohn konnte das Ideal des Menschen bedeuten)" [6. P. 19]. So, as we can see, Jesus — in the representations of Christian art - is not merely the ideal of the human being and God; he is the ideal of the human being because he is God.

In Ästhetik des reinen Gefühls, as we have already stated, Cohen's perspective on Greek sculpture completely changes. Greek sculpture really represents the ideal of the human figure, so we have to ask an important question: if in Kants Begründung der Ästhetik the representation of Jesus is a decisive advance in comparison to Greek sculpture, in Ästhetik des reinen Gefühls (where Cohen recognizes that the Greek sculptural masterpieces representing gods are representations of the ideal of the human figure), does the representation of Jesus differ from the representation of gods in Greek sculpture?

The examination of the problem of the representation of Jesus in Ästhetik des reinen Gefühls should begin from a preliminary remark: whereas in Kants Begründung der Ästhetik Cohen devotes to the representation of Jesus just a short consideration in the historical introduction of the book, in Ästhetik des reinen Gefühls the representation of Jesus is the object of far more attention. We find in this work by Cohen both a short theoretical examination of the question of the possibility to represent Jesus as God and a lot of comments about many artworks representing the figure of Jesus.

However, when Cohen writes Ästhetik des reinen Gefühls, his perspective on Christianity and on its doctrine of incarnation has become far more negative.

The most meaningful document of Cohen's perspective about incarnation in the period of Ästhetik des reinen Gefühls is probably a short writing entitled Die religiösen Bewegungen der Gegenwart (1914) ${ }^{4}$. Here Cohen still states that the best view of incarnation is to consider Jesus not as a historical individual, but as the idea of humanity. Cohen names Leibniz and Kant as the main representatives of this view [5. Vol. I. P. 44-45, 2. Vol. XVI. P. 134], but he also mentions a protestant theological tendency of his time, according to which the historical existence of Jesus can (or must) be denied, because the religious consciousness points to the

\footnotetext{
${ }^{4}$ Republished in [5. Vol. I. P. 36-65, 2. Vol. XVI. P. 121-162].
} 
ideal and internal Christ, not to a historical individual ${ }^{5}$. However, whereas in the 80s Cohen considers incarnation (if interpreted this way) as an important and authentic religious thought, in Die religiösen Bewegungen der Gegenwart he criticizes the doctrine of incarnation even in this idealized version. As a consequence of the doctrine of incarnation, he states, in Christianity the fundament of personal morality lies in following Jesus, following the person of Christ as God that became a human being. If the person of Jesus and his story are considered to be the fundament of morality, morality loses its autonomy, whether this person and his story are considered as historically true or they are considered as just ideal and imagined. So Christian morality is, according to Cohen, necessarily heteronomous.

On the contrary, in Judaism, no human being — not even Moses - can be considered to be perfect and identified with the idea of humanity. The very concept of the Messiah, according to Cohen, is not the concept of an individual human being, because the Messiah is the people of Israel (or its remnant), or also - in ultimate perspective - the whole mankind. According to Cohen, it would be more precise to speak about a messianic age, not about a Messiah. For this reason, Cohen thinks that the identification of the Messiah with the Christ - both words mean "anointed", the first in Hebrew, the second in Greek - has to be rejected.

Now that we have stated these general features of Cohen's view of Christianity, we can come back to the specific analysis of what Cohen writes in Ästhetik des reinen Gefühls about the artistic representation of Jesus. We find a brief theoretical examination of the question of the possibility to represent Jesus as God in the chapter about sculpture; here Cohen expresses, with reference to sculpture, his general considerations on the authentic object of artistic representation, that is the human being. So, the representation of Jesus as God is an ideal that is contrary to the aims and to the possibilities of sculpture [1. Vol. II. P. 290-291]. As a consequence of that, sculpture, in an age completely dominated by Christianity, necessarily encounters difficulties; so, in the Middle Ages sculpture does not have real autonomy, but it is just an ornament of architecture [1. Vol. II. P. 291]. This lack of autonomy persists until the Renaissance, when sculpture slowly regains artistic autonomy because it regains cultural autonomy from religion.

These statements do not mean that according to Cohen the representation of Jesus is necessarily doomed to artistic failure, i.e. to an insufficiency in the realisation of the idea of beauty. However, if we examine Cohen's considerations about masterpieces in the history of sculpture, we clearly see that Cohen, concerning the representations of Jesus that he considers to be authentic masterpieces, states that in them Jesus is represented as merely human. There are two sculptural representations of Jesus particularly praised by Cohen. The first is

\footnotetext{
5 For this tendency in the protestant theology of Cohen's time, see Hartwig Wiedebach's footnote 1 in [2. Vol. XVI. P. 133]. Among the representatives of this theological tendency there was Wilhelm Herrmann, who taught in Marburg and had a personal acquaintance with Cohen. Regarding the relation between Cohen and Herrmann, see Chapter 8 of [7] and [8]. To Cohen's relation with protestant theology is devoted [9].
} 
the sculptural group The Incredulity of Saint Thomas, by Verrocchio; Cohen states that it is the most beautiful representation of Jesus in sculpture, and perhaps in all figurative arts; Jesus is represented as the teacher of the incredulous. In being represented as teacher, Cohen sees the representation of Jesus as merely human [1. Vol. II. P. 292]. The second one is Michelangelo's Vatican Pietà, about which Cohen writes some larger considerations in comparison to the cursory comment about Verrocchio's work. In Vatican Pietà Jesus' body, although dead, is not void of expression; rather, the last remains of vitality that still seem to enliven the right hand express the consciousness to have achieved the fulfillment. However, what Cohen considers fulfilled here is not the divine mission of redemption, but rather the fact that Jesus shows himself as a human being. Jesus, dead on the lap of his mother, is completely, merely human [1. Vol. II. P. 300-301]. In this complete humanity, the autonomy of art affirms itself, that is to say here is affirmed the autonomy of art to take the contents of religion and of myth and to make of those contents the matter for the production of its own authentic and specific content (that is, aesthetic consciousness itself). At the same time, this mere humanity of Jesus shows Michelangelo's freedom in dealing with religious themes: the representation of Jesus dead on the lap of his mother becomes the authentically individual representation of a man, of his life and of his destiny, without any enslavement to dogmatics or any compromise with the myth of incarnation.

Are Cohen's considerations about sculpture also valid for painting? First, we have to notice that, whereas the representation of Jesus in sculpture is the object of a brief theoretical analysis, there is no similar analysis for the representation of Jesus in painting. However, Cohen examines many works of painting that represent Jesus, whereas in the chapter about sculpture he examines few works representing the same subject.

The first painter whose work is the object of direct consideration by Cohen is Giotto; with reference to Giotto's works, Cohen expresses his fundamental thought about the representation of Jesus in painting. The starting point of these considerations is the necessary autonomy of art from religion and its dogmas. It is not important to know which religious beliefs and attitudes the artist had from a biographical point of view; independently from the artist's personal religious ideas, pure feeling autonomously produces its own object according to its own legality [1. Vol. II. P. 333-334].

Also in painting, the authentic object of representation is the human being, the human figure, not God. However, there is an important difference in comparison to sculpture: both pictorial and sculptural figures put together two aspects, that Cohen names "nature of man" (Natur des Menschen), which is the representation of the unity of body and soul, and "man of nature" (Mensch der Natur), which is the representation of the individual in its environment, in the world that surrounds the individual, and of the links between the human being and this environment (that is both natural and historical or social) ${ }^{6}$. The human being cannot be represented in

\footnotetext{
${ }^{6}$ About the expressions "Natur des Menschen" and "Mensch der Natur", see [3. P. 147-152, 4. P. 136].
} 
its unity as completely isolated; the will, the wishes, the affects of the individual point beyond the individual itself. The feature of painting in comparison to sculpture is that in painting this second aspect, the unity of the human being and its environment, has far more importance [1. Vol. II. P. 310-312], whereas sculpture is par excellence the art that brings to representation the first aspect in a single figure [1. Vol. II. P. 242-244]. For this reason, in painting, far more than in sculpture, the representation of a character is at the same time the representation of its story; this is fundamental to understand Cohen's considerations about the pictorial representation of Jesus.

As in sculpture, also in painting the representation of Jesus has to be the representation of a human being, not of God. Cohen writes that Giotto "brings to representation the purely human and the purely moral (das rein Menschliche und das rein Sittliche) in the whole story of faith (Glaubensgeschichte) of Christ almost without exception" [1. Vol. II. P. 330]. By the words "the purely human and the purely moral" Cohen states that we do not have to consider theological doctrines about the divinity of Jesus as a fundament of Giotto's representation of Jesus, because the story that is represented in those paintings is merely human. At the same time, Cohen also states with these words that the story of Jesus has an ideal and universal meaning, a symbolic value with reference to the life of every human being. This is possible as a consequence of a fundamental aspect of Christianity, which is that Christianity sees suffering as the destiny of the human being. Thanks to that, the story of Jesus is represented by Giotto as the ideal story of the human being [1. Vol. II. P. 331].

If this ideal story is a story of suffering, and if suffering is the destiny of the human being, suffering itself cannot be seen as a denial of human life, or as a contradiction to human life; rather, it is absolutely essential to human life itself. The fundament of art, we should remember, is pure feeling, or love for the human being; so, art has to love the human being in suffering as well, in that suffering that is the destiny of the human being. As a consequence, art cannot represent suffering in an exclusively dreadful way. For this reason, Cohen emphasizes that, in Giotto's paintings representing the passion and the death of Christ, the representation of suffering is not too dramatic; here suffering is transfigured by love. So, this representation of Christ is an authentic paradigmatic expression of this love for the human being in suffering.

The ideal meaning of the representation of Jesus is also the fundament to answer the question about the representation of the divine in Jesus' figure; Cohen writes that for Giotto "the suffering of Christ is divine suffering, because the morality of the human being shows itself in him, and in morality his destiny, his essence (Wesen), his nature" [1. Vol. II. P. 331]. So, we can see that the suffering of Jesus is divine suffering only in that it is the symbol and the ideal of the story and the destiny of every human being; in artistic representation, the divinity of Christ is deprived of its theological meaning and reduced to the symbolic value of the story of Jesus.

The ideal value of the story of Jesus, however, seems to have two aspects: according to the first, it embodies every human being's destiny of suffering; 
according to the second, in Jesus is revealed the morality of the human being. Perhaps we could think, at first sight, that the link between these two aspects is not fully justified: if suffering is the destiny of every human being, we can think, the wicked one suffers as much as the righteous one. Actually, Cohen (who examines the problem of the supposed relation between suffering and guilt in many of his writings about religion) thinks that it is fundamental that the consideration of the suffering of man is separated from the consideration of his guilt, because otherwise it would be obvious to see suffering as punishment. For this reason, the possible guilt of the suffering person should have no role in the artistic representation of the ideal story of the human being as a story of suffering; in order that suffering represented by art can authentically have ideal value, the suffering person has to appear as innocent; so, in Christian art, the suffering of Christ truly has an ideal value because Christ is the innocent or the righteous par excellence.

As we can see, this interpretation of the story of Jesus (in his pictorial representation) as the ideal story of the human being is clearly in consonance with Cohen's view on incarnation, according to which Jesus should not be considered as a historical individual, but as the idea of humanity. However, we can say, here art takes a step forward in comparison with the mere consideration of Jesus as the idea of humanity: art sees in this ideal value of the story of Jesus the meaning of the divinity of Jesus himself, of his being God, not merely human. On the contrary, in Religion der Vernunft (posthumous, 1919) Cohen states that from the point of view of religion even this symbolic interpretation of the divinity of Christ has to be rejected: in the statement of the unicity of God there is no symbolism, and introducing any symbolism in this statement should be an obfuscation of truth [10. P. 484-485]. So, a question now becomes unavoidable: how is it possible that the recognition of Christ as an ideal (for his story) and of his divinity in a symbolicmetaphoric meaning has an authentic validity in art, and at the same time has to be rejected in religion? Is the systematic harmony of culture not torn apart by this opposition? Actually, it is a characteristic of art (and something that distinguishes art from every other aspect of culture), that in its figures we can recognize the full realisation of an ideal; for instance, the figures of the Greek gods are full realisations of the ideal of the human figure. In the same way, the artistic representation of Jesus and of his story can authentically be the representation of the ideal story of the human being. So, it is not the story of Jesus in itself that is the ideal story of the human being, but the story of Jesus as represented that way by art (that is to say: art does not passively receive the story of Jesus as provided with universal value in itself, but rather art autonomously produces representations of the story of Jesus as the ideal story of the human being).

The value of the full realisations of the ideal in art, however, is authentic and at the same time illusory. Art is indeed the kingdom of illusion: sculptural figures of the Greek gods fully realize the ideal of human figures, but they aren't real living beings. So, also the Christ represented by painting isn't a real person who is living a true story; for this reason, the ideal value of his story is fully valid only in the field where the artistic illusion is valid, that is the field of art itself. 
In light of these considerations, it is possible to come back to Cohen's examination of the great masterpieces of sacred painting. An important feature of this examination can appear clearly through a comparison posed by Cohen between Giotto and Leonardo, who is the second painter whose works are explicitly examined by Cohen. The fundamental feature of Leonardo's painting consists in the fact that Leonardo devoted his work to the problem of portrait; what consequences does that have on his pictorial representations of Jesus? Cohen writes that in Leonardo's works the representation of Jesus and of Mary is portrait-like; Leonardo follows Giotto in his symbolic interpretation of the story of Jesus, so that also in Leonardo's works the story of Jesus is the ideal story of the human being. However, the figure of Jesus painted by Leonardo is more human than the one painted by Giotto, because it is more portrait-like; Jesus is represented as a real individual, whereas Giotto's Jesus is still an ideal figure, not so different from the sculptural figures of the Greek gods, above all Apollo [1. Vol. II. P. 341-342]. All this does not mean that the faces of Jesus and Mary represented by Leonardo do not have a perfect beauty that competes with the one in Giotto's works. A portrait is the representation of real beings, not of ideal beings (like the Greek gods), but this does not mean that these real beings are not idealized by pure love that produces them as objects of artistic representation. Confusion has to be avoided between the representation of real beings and strictly realistic representation; Cohen writes in Ästhetik des reinen Gefühls [1. Vol. I. P. 297] that there is no portrait without idealisation. The idealisation of the figure of a real human being is clearly an idealisation founded in love, an idealisation that recognizes the ideal in the finite; so, the face of the man who is the object of a portrait can have a perfect beauty, but this idealisation is different from the sublime idealisation that makes of its object a superhuman being, as gods in Greek art.

Regarding this feature of Leonardo's representation of Jesus, Cohen's statements are however quite fluctuating; on a general level, Cohen states that Leonardo painted Jesus' image as portrait-like, however his own analysis of Leonardo's works, like the Last Supper, does not fit with this general thesis. Cohen indeed considers Jesus' face in the Last Supper to be sublime, as an expression of perfect goodness, of goodness that cannot be human, but is exclusively divine [1. Vol. I. P. 304-307]; so, this representation cannot be portrait-like. Perhaps Cohen is more convincing in stating that Leonardo's sacred works of painting are portrait-like in representing Mary [1. Vol. II. P. 342-343]. In any case, we can observe that the portrait-like representation of Jesus fulfils the humanisation of Jesus himself. He is represented not merely as an individual, but as a real individual.

Obviously, we can now ask if the fact that Jesus is represented as a real human being implies that the universal value that has been attributed to his story has to be denied. Actually, this is not a true problem: every human being represented by art is an individual endowed with universal value. This answer, however, immediately raises a new question: if every human being represented by art has universal value, how can we recognize in the representation of Jesus and of his story a superiority 
or a primacy concerning the universality of its value in representing the ideal story of the human being - in comparison (for example) to the representation of the poor working people in paintings by Jean-François Millet or Max Liebermann?

As religion is not a fundament of the artistic validity of any artistic creation, the value that we metaphorically call "divine" in the representation of Jesus is not exclusively due to the representations of his story, but it can be recognized to the representation of every human being. So, the statement according to which the story of Jesus is the ideal story of the human being can only mean the particular clarity with which the story of Jesus seems to represent the destiny of everyman. However, is this clarity sufficient to state that the story of Jesus is the ideal story of the human being? Couldn't other stories represented by art claim to be the ideal story of the human being and to have the same clarity? We do not find an explicit answer in Ästhetik des reinen Gefühls; however, we have to remember that in Der Begriff der Religion im System der Philosophie (1915) Cohen states that the suffering Christ is merely an aspect of the human being, a partial image of the human being; the ideal image of the human being cannot be completely summed up in suffering, as it is expressed in the story of Jesus; the ideal image of the human being seems to be rather embodied in Faust, that is to say in the human being who actively woks in effort and pain, and addresses his own hard work towards the last goals of human freedom, searching and finding redemption in this hard work [11. P 132-133].

We can say that with the analysis of the works of those two painters, Giotto and Leonardo, Cohen fully exposes his theses about the problem of the artistic representation of the divine in Jesus' figure. Cohen's comments on artistic representations of Jesus continue in his considerations about later painters; however, these comments by Cohen seem to provide merely little additions to what has already been presented.

Concerning Raffaello, Cohen briefly deals with his representations of Jesus as a child, in paintings in which Mary appears as the main figure [1. Vol. I. P. 303]. Cohen considers Raffaello to be a master of what he names Humor, which consists in recognizing the infinite in figures characterised by ugliness, or littleness, or weakness ${ }^{7}$. In Raffaello's representations of Jesus as a child, the infinite is recognized in the figure of a child, with his weakness and his immaturity. Here Cohen highlights the Humor of representing Christ as a child: while he plays with another child, like every child, his gaze penetrates all the things in the world. However, we do not have to understand this remark as the statement that the theological Christian dogma of the divinity of Jesus is the foundation of the artistic value of Raffaello's representations of Jesus as a child: the infinite recognized by Humor in figures of ugly or weak human beings is the human being itself in its dignity as an object of pure feeling; this is a purely aesthetic infinite, not a religious one. So, the representation of Jesus as a child seems only to provide a particularly clear example of a Humor that can be found in every authentic artistic representation of children.

\footnotetext{
${ }^{7}$ About Cohen's concept of Humor, see [12. P. 140—147, 4. P. 149—183].
} 
Humor has also a central role in Cohen's brief comment on Holbein's Jesus before Caiaphas; however, whereas in Raffaello's representations of Jesus as a child Humor consists in recognizing the infinite in the figure of a child (with his weakness and his immaturity), in this work by Holbein the infinite is recognized in the figure of Jesus as a humiliated man, as a man that is made ugly by the humiliation to which is undergone [1. Vol. II. P. 374].

Concerning Michelangelo, Cohen does not take into examination specific pictorial representations of Christ, but some of his reflections are important for our topic; they concern the usually less considered parts of the ceiling of the Sistine Chapel, that is to say the painting in the spandrels and in the lunettes. Cohen highlights the poverty of the persons represented in the familiar scenes that Michelangelo painted here, and favourably considers the hypothesis that these paintings do not represent the ancestors of Jesus (which is the most common interpretation), but the Jewish people in exile [1. Vol. II. P. 357-358]. What is important for the question of the representation of the divine is that in this context - the celebration of familiar virtues in the life of poor and suffering persons - Cohen sees the most heartfelt pictorial representations of the sacred family and the most beautiful Madonnas [1. Vol. II. P. 363]. So, Cohen's comments on these paintings by Michelangelo appear to be a clear confirmation of what has been stated before about the value of portrait, because they show the complete homogeneity of the representation of Jesus and Mary with the representation of any person; since Jesus and Mary appear as mere human beings, every family, in particular a poor and suffering one, is for art, in its autonomy from religion, the sacred family, every mother with her child is Mary.

Dürer's religious works, as with the works of some of the previously mentioned painters, are considered from the point of view of the portrait; Dürer's peculiarity, in comparison with the previously examined painters, derives from the fact that Dürer is the painter of the Reformation [1. Vol. II. P. 365 $]^{8}$. With the separation of German Christians from the Catholic Roman Church, a necessity of a new awareness of the peculiar features of the German people rises in Germany; Dürer therefore represents in his paintings the typical figure of the German man and woman'. This can be observed above all in his Madonnas, which are like portraits

\footnotetext{
${ }^{8}$ Actually, Cohen takes into examination several works by Dürer, not few of which were painted by Dürer (who died in 1528) before 1517; it is clear, therefore, that Cohen does not strictly make reference to the Reformation as a precise historical process beginning in 1517 , but to a religious and cultural climate that had begun earlier and that had the facts of 1517 and of the following years as its expression and consequence.

${ }^{9}$ This relevance of Protestant religion and of national belonging for Dürer's art is at the basis of some critical remarks by Cohen, that points at the risk, for Dürer's art, to lose its aesthetic purity and its reference to all humanity, and to be subordinated to confessional propaganda or to national identity; see [1. Vol. II. P. 366-370]. Hartwig Wiedebach, in his book about the national element in Hermann Cohen's thought, put these remarks in relation to Cohen's considerations on the question of the significance of physiognomy for the notions of people, nation and nationality; see [13. P. 147-148].
} 
representing typical German women or mothers; clearly, the representation of the face or of the figure of Mary with typical German features shows that the representation of the divine in the human being, or of the participation of the human being in the divine, is fully independent from the adherence to sacred history. So, it is restated that art can recognize and represent in any individual — not exclusively in those figures that are given to art as a model by religion and Church - the participation of the human being in the divine.

Dürer's historical role as the painter of the Reformation is also connected, according to Cohen, to the fact that Dürer painted representations of Christ as selfportraits, or self-portraits with typical features of the representation of Jesus; following the spirit of Reformation, Dürer had to find the spirit of Christ in himself, in his own personal consciousness. So, self-portrait is a suitable kind of painting for the representation of the typical German face and for the expression of the spirit of Christ in the German Protestant Christian. As it can be clearly seen here, according to Cohen, the Reformation set Christianity free from the mythic unicity and historical individuality of Christ, making Jesus present in every believer ${ }^{10}$.

As Cohen's examination of the great painters of history goes on, the attention devoted to religious artworks diminishes; the last painters whose religious works are the objects of some comments by Cohen are Rembrandt and Velasquez. However, in the case of Velasquez, these are very brief and do not really add anything to his already examined considerations of the representations of Jesus [1. Vol. II. P. 395]. Rembrandt's religious works, on the contrary, are the object of more attention. Concerning his pictorial representations of Jesus, Cohen emphasized above all two aspects: the first is that, after remarking that the representation of Jesus is portrait-like in Rembrandt's works as well, Cohen states (with reference, above all, to the Supper in Emmaus [1. Vol. II. P. 381]) that the portrayed face has here Jewish features; Cohen emphasizes indeed the frequency Jewish faces have in Rembrandt's works. The second aspect is the setting of sacred scenes among common or poor people; Dutch painters often used to paint scenes of the life of common or poor people, but the setting of sacred scenes among those people is used by Rembrandt to make the sacred profane, or to erase the divide and the contraposition that, according to an irreligious prejudice [1. Vol. II. P. 388], could separate the common life of human beings from the sacred. Cohen particularly mentions Rembrandt's Hundred Guilders Print [1. Vol. II. P. 388], where we see Jesus delivering the ill persons on his left from their diseases, and at the same time welcoming the children on his right. Clearly the setting brings the scene to everyday life; however, Cohen emphasized above all that Jesus' attitude towards children makes him a moral educator. In light of that, Cohen also reads the

\footnotetext{
${ }^{10}$ These considerations about Dürer's representations of Christ as self-portraits, or self-portraits with typical features of the representation of Jesus, are not clearly expressed by Cohen in Ästhetik des reinen Gefühls, where we find only a brief reference to this topic [1. Vol. II. P. 371], but in Über das Eigentümliche des deutschen Geistes (1914), republished in [14. Vol. I. P. 527-570] and [2. Vol. XVI. P. 237-297]; see [14. Vol. I. P. 561] or [2. Vol. XVI. P. 285].
} 
other half of the engraving, stating that the miracles of healing also have to be interpreted in a moral sense, as liberation from evil and from moral blindness. So, according to Cohen, artistic creation makes itself independent from the mythical-dogmatic aspects of faith - in this case from miracles - giving them an exclusively human and moral meaning.

At the end of this historical review of the representations of Jesus by several great painters, we can answer the question (that was asked some pages ago) about the difference between the artistic representation of Jesus and that of Greek gods. As we have already seen, in Kants Begründung der Ästhetik Cohen states that only Jesus, not Greek gods, can be represented by art as the ideal human being; in Ästhetik des reinen Gefühls, on the contrary, Cohen recognizes that the masterpieces of Greek sculpture representing gods are representations of the ideal of the human figure. So, what can the difference be between the representation of Jesus and that of Greek gods? The difference is that Jesus' figure is not the ideal human figure, but rather his story is the ideal story of the human being. For this reason, the representation of Jesus is more suitable for painting (which represents the human being in the context of an environment - and so in the context of a story) than for sculpture, which represents mainly the human being alone.

The main question about the artistic representation of Jesus, however, concerns the possibility of representing God or the divine through the representation of Jesus. As we can clearly verify from Cohen's reflections that have been examined so far, in Ästhetik des reinen Gefühls the consideration of the representation of Jesus as the representation of an individual of universal value is not separated from the view according to which he is represented as a mere human being, not as God. Even if in the representation of Jesus the participation of the human being in the divine or the divine value of the human being are someway expressed, the divinity of Jesus as represented by art is reduced to a symbolic or metaphorical meaning.

So, it is possible, in conclusion, to express a critical consideration on what Cohen writes in Ästhetik des reinen Gefühls about the representation of Jesus. Cohen is very convincing in defending a kind of specifically and autonomously aesthetic validity of works of art (including works of sacred art) independently from the religious (or moral, or politic) content that these works can communicate. So, Cohen is also convincing in stating that the fundament of the specifically aesthetic validity of every artistic representation of Jesus cannot be the divinity of Jesus himself; as a consequence, it also seems correct that Cohen abandons the statement expressed in Kants Begründung der Ästhetik (which really was just a statement, more than an argued thesis) according to which Jesus, in his artistic representations, can be the ideal of the human being because he is at the same time God.

However, Cohen does not seem to restrict himself to excluding the divinity of Jesus from the foundation of the aesthetic validity of his artistic representation; rather, Cohen seems to exclude the divinity of Jesus also from the matter of art, completely reducing this divinity to its symbolic or metaphoric meaning. This is really not so convincing, however. The statement that the divinity of Jesus cannot 
be the fundament of the aesthetic validity of his pictorial representation does not imply that, for the understanding of the artworks representing Jesus, it is irrelevant that the matter of the representation is derived from a myth (according to Cohen's consideration of the fundamental story of Christianity as a myth) in which Jesus is really God, not merely the ideal of the human being nor a particularly clear example of the participation of the human being in the divine.

If we imagine, for example, a painter that represents in a work of his a mythological scene, it is clear that he can (or must) idealize the myth from which he draws the matter of his work. However, in this work Zeus is nonetheless Zeus, with all his attributes; any symbolic interpretation of the figure of Zeus cannot completely dissolve his mythical role and identity. Cohen, in his consideration of the sculptural figures of the Greek gods as ideal human figures, does not claim that the mythological attributions of these figures have to be denied.

On the contrary, concerning the Christian myth, Cohen seems to demand that its artistic idealisation, in order to represent it as the ideal story of the human being, brings the divinity of Jesus to dissolve completely into its symbolic meaning. If the divinity of Jesus is only a metaphor for the value of Jesus' story as the ideal story of the human being, Cohen seems to demand that this metaphor becomes so transparent as to disappear, converting itself into the direct identification of the story of Jesus with the ideal story of the human being.

So, it seems necessary to acknowledge that, concerning the artistic representation of Jesus, Cohen embraced a stance that implies the unpleasant consequence that in this case art does not restrict itself to use sovereignly its matters for the production of its own content, but distorts its matters, rather than bringing them to a full idealisation. So, we can state that Cohen's attitude towards

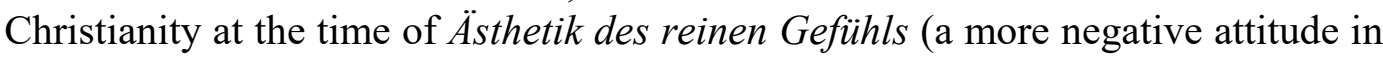
comparison to that of the 80s) expresses itself also in Cohen's consideration of Christian art: sacred Christian art has produced great masterpieces, but that has been possible, according to Cohen, exclusively through the estrangement (more than through the autonomy) of artistic production from the dogmatic contents of Christianity itself, and first of all from the central feature of Christianity, i.e. incarnation.

\section{References}

[1] Cohen H. System der Philosophie. Dritter Teil: Ästhetik des reinen Gefühls. 2 Vols. Berlin: Bruno Cassirer; 1912. Anastatic reprint as Vols. VIII and IX of [2].

[2] Cohen H. Werke. 17 Vols. (+ 2 Vols. Supplementa). Ed. Hermann-Cohen-Archiv, Hildesheim et al.: Olms; 1977ff.

[3] Poma A. Yearning for Form and other Essays on Hermann Cohen's Thought. Dordrecht: Springer; 2006.

[4] Gamba E. La legalità del sentimento puro. L'estetica di Hermann Cohen come modello di una filosofia della cultura. Milano-Udine: Mimesis; 2008.

[5] Cohen H. Jüdische Schriften. Ed. B. Strauß. 3 Vols. Berlin: C.A. Schwetschke \& Sohn; 1924. 
[6] Cohen H. Kants Begründung der Ästhetik. Berlin: Dümmler; 1889. Anastatic reprint as Vol. IV of [2].

[7] Kluback W. The Idea of Humanity. Hermann Cohen's Legacy to Philosophy and Theology. Lanham et al.: University Press of America; 1987.

[8] Fischer-Appelt P. Wilhelm Herrmann und Hermann Cohen. Der frühe Diskurs um die Selbstwerdung des Menschen. In: Religion aus den Quellen der Vernunft: Hermann Cohen und das evangelische Christentum. Tübingen: Mohr Siebeck; 2012. P. 116-128.

[9] Dober HM, Morgenstern M, editors. Religion aus den Quellen der Vernunft: Hermann Cohen und das evangelische Christentum. Tübingen: Mohr Siebeck; 2012.

[10] Cohen H. Religion der Vernunft aus den Quellen des Judentums. 2nd edition. Ed. B. Strauss, Frankfurt a.M.: Kaufmann; 1929.

[11] Cohen H. Der Begriff der Religion im System der Philosophie. Gießen: Töpelmann; 1915. Anastatic reprint as Vol. X of [2].

[12] Poma A. The Critical Philosophy of Hermann Cohen. Engl. transl. J. Denton. Albany NY: SUNY; 1997.

[13] Wiedebach H. The National Element in Hermann Cohen's Philosophy and Religion. Engl. transl. W. Templer. Leiden-Boston: Brill; 2012.

[14] Cohen H. Schriften zur Philosophie und Zeitgeschichte. Ed. A. Görland and E. Cassirer. 2 Vols. Berlin: Akademie-Verlag; 1928.

\title{
About the author: \\ Gamba Ezio — PhD in Philosophy and Philosophical Hermeneutics, University of Turin; Indentured Professor, Theological University of Northern Italy - Turin Campus, Turin, Italy (e-mail: ezio.gamba.1975@gmail.com). \\ Художественное изображение Иисуса в эстетике Германа Когена
}

\author{
Эцио Гамба $₫$ \\ Теологический университет Северной Италии - Туринский кампус, \\ Italy, 10122, Turin, Via XX Settembre, 83 \\ \ezio.gamba.1975@gmail.com
}

Аннотация. Герман Коген затрагивает вопрос о возможности искусства представлять Бога или божественное в некоторых своих работах на протяжении всей своей философской деятельности, но, очевидно, прежде всего, в своем главном эстетическом произведении, «Эстетика чистого чувства» (Ästhetik des reinen Gefühls, 1912). Мы можем констатировать, что в работах Когена эта проблема ставится применительно к трем различным религиозным областям: греческий политеизм, иудейский монотеизм и христианство. Темой представленной статьи станут размышления Германа Когена о художественном изображении божественного в христианстве или в христианском искусстве через изображение Иисуса. Мы рассмотрим данную проблематику со ссылкой как на «Обоснование Кантом эстетики» (Kants Begründung der Ästhetik, 1889), так и на «Эстетику чистого чувства» (Ästhetik des reinen Gefühls). Если в «Обосновании Кантом эстетики» Коген уделяет изображению Иисуса лишь небольшое внимание в историческом введении книги, то в «Эстетике чистого чувства» изображению Христа уделено гораздо больше внимания. Ответ Когена на вопрос о возможности представления 
божественного через изображение Иисуса заключается в том, что божественность Иисуса в художественном изображении его фигуры может иметь только метафорическое значение, реальный смысл которого заключается в том, что история Христа является идеальной историей человеческого существа. В «Обосновании Кантом эстетики» и в других работах 1880-х гг., напротив, идея воплощения и божественности Иисуса является объектом иной оценки Когена. Сравнение разных позиций может стать вкладом в осмысление изменений во взглядах Когена на христианство в течение долгих лет.

Ключевые слова: Герман Коген, эстетика, Иисус Христос, христианство, религиозное искусство, греческая скульптура

\section{История статьи:}

Статья поступила 08.06.2021

Статья принята к публикации 15.08.2021

Для цитирования: Gamba E. The Artistic Representation of Jesus in Hermann Cohen's Aesthetics // Вестник Российского университета дружбы народов. Серия: Философия. 2021. T. 25. № 3. C. 404 419. DOI: 10.22363/2313-2302-2021-25-3-404-419

\section{Сведения об авторе:}

Гамба Эции - доктор философии, Университет Турина; профессор, Теологический университет Северной Италии - Туринский кампус, Турин, Италия (e-mail: ezio.gamba.1975@gmail.com). 